\title{
Parent Perspectives of Desired and Experienced Child and Family Practices in the Early Elementary Grades
}

\author{
Carl J. Dunst* \\ Orelena Hawks Puckett Institute, 128 S. Sterling St., Morganton, NC 28655 \\ Email: cdunst@puckett.org \\ Deborah W. Hamby \\ Orelena Hawks Puckett Institute, 128 S. Sterling St., Morganton, NC 28655 \\ Email: dhamby@puckett.org
}

\begin{abstract}
Knowledge of the types of school-based practices parents consider important for their children and themselves are the foundations for improving school-family relationships. Surveys were used to determine parents' (1) desire for family-centered practices, individualized and developmentally appropriate child practices, and integrated and coordinated child and family practices in the early elementary grades, (2) the extent to which parents and their children experienced desired practices, (3) barriers and solutions to use of the practices, and (4) strategies and recommendations for promoting increased use of desired practices. Participants were parents of children with disabilities or developmental delays who previously participated in early intervention or preschool special education programs, or both, where the children were currently enrolled in grades $\mathrm{K}$ through 3 at the time data collection occurred. Findings indicated that the desire for targeted practices varied depending on the types of practices, the parents and children minimally experienced desired practices, and that barriers and solutions tended to be related to family-school relationships. Implications for improving school-family relationships and practices are described.
\end{abstract}

Keywords: Family-centered, developmentally appropriate, inclusion, integrated, coordinated, desired practices, experienced practices, barriers, solutions

DOI: $10.7176 / \mathrm{JEP} / 10-15-05$

Publication date:May $31^{\text {st }} 2019$

\section{Introduction}

The study described in this paper was conducted as part of a research institute charged with bridging the gap between early childhood intervention (ECI) practices and elementary school practices (Le Tendre, 2000; Yeboah, 2002). A major goal of the institute was to develop, evaluate, and disseminate strategies and procedures that could move successful early intervention and preschool practices into the early elementary grades. A secondary goal was to identify barriers and solutions to the adoption of these practices, as well as recommendations, strategies, and procedures for promoting increased use of desired ECI practices in the early elementary grades. The results were expected to inform the kinds of practices that were important to families and in which ways school-family relationships could be improved.

The study focused on the desire for and use of (1) family-centered practices (Dunst \& Espe-Sherwindt, 2016), (2) individualized and developmentally appropriate child intervention practices (Niemeyer, Cassidy, Collins, \& Taylor, 1999), and (3) integrated and coordinated child and family practices (Bruder, 2005). All three types of practices are considered best practices in the birth to age six early intervention and preschool years (Bailey \& McWilliam, 1993; Odom \& McLean, 1996). Those aspects of family-centered, individualized and developmentally appropriate, and integrated and coordinated practices examined in the study were ones for which there is both general consensus and/or agreement about the desirability of the practices for both children and families and an increasing amount of evidence for the benefits of the practices (e.g., Dunst, 2017; Dunst, Trivette, \& Hamby, 2008; Farley, Brock, \& Winterbottom, 2017; Odom, Buysse, \& Soukakou, 2011). According to Bailey (1994), family-centered early intervention has four specific features and characteristics: “(1) Family support is a primary goal of any early intervention activity..., (2) each family has its own culture and unique set of strengths, values, skills, expectations, and service needs..., (3) families have a right and a responsibility to play a primary role in determining the nature and extent of services provided for themselves and their child..., and (4) to provide appropriate services for families, a coordinated system of services must be in place" (pp. 27-28). Individualized practices are ones that are responsive to child and family concerns and priorities and include the use of informal and formal resources, strategies, and techniques tailored to each individual child and family's situation (Aaron et al., 2014; Turbiville, Turnbull, Garland, \& Lee, 1996). Developmentally appropriate practices also emphasize child-initiated learning, teacher responsiveness to child interests, and the use of curricular materials and methods that promote and enhance development at a pace best suited to each individual child's learning style (McKenzie, 2013; Ruble \& McGrew, 2013). Integrated and coordinated service delivery refers to practices involving 
opportunities for joint planning and collaboration among professionals and between professionals and parents (Bruder, 1994; Rainforth \& York-Barr, 1997), coordinated and integrated delivery of services to children and their families (Salisbury, 1992), and the inclusion of children with disabilities in typically occurring school programs and activities (Peck, Odom, \& Bricker, 1993; Wolery \& Wilbers, 1994).

Previous research has found differences in desired and experienced family-centered practices among both ECI practitioners and parents of young children participating in ECI programs (see Dunst, 2002 for a review). Similar results have been found in studies of professionals and parents of children in the early elementary grades (Dunst \& Trivette, 2009; McWilliam, Maxwell, \& Sloper, 1999). Results from these studies indicate that the study participants experienced less family-centered practices than they desired. Findings from studies of developmentally appropriate practices (e.g., Trivette, Dunst, Hamby, \& Meter, 2012) and integrated and coordinated practices (e.g., Institute of Medicine, 1997; Kavale \& Forness, 2000) also indicate a discrepancy between desired and experienced practices. The study described in this paper differed from previous investigations by obtaining parents' judgments of three different kinds of ECI practices rather than only one type of practice. This permitted comparisons of similarities and differences in both desired and experienced recommended practices in the early elementary grades.

\subsection{Purpose of the Study}

The study described in this paper focused specifically on family perspectives of family-centered practices, individualized and developmentally appropriate child practices, and integrated and coordinated practices being used with children having identified disabilities, developmental delays, or academic-related problems in grades $\mathrm{K}$ through 3 where all of the children had previously participated in ECI. We examined the desire for these practices, the extent to which parents and their children experienced the practices, the barriers (problems, concerns, etc.) associated with the use of desired practices, and the solutions and recommendations parents identified as strategies for increasing the adoption of desired practices. The results were expected to shed light on highly desired practices, the extent to which the practices were experienced by the children and other family members, and both barriers and solutions to for increasing the use of the practices.

\section{Method}

\subsection{Participants}

The participants were 52 parents of children with identified disabilities or developmental delays and children atrisk for poor outcomes who had participated in birth to age 3 early intervention and/or age 3 to 5 preschool programs. The parents were recruited from two programs in urban settings in western Pennsylvania (PA) and two programs in rural settings in western North Carolina (NC). Early intervention and preschool program directors agreeing to assist with the investigation sent both a letter from the investigators to program participants explaining the study and a cover letter from the program directors inviting the parents to participate in the study. The letters were sent to parents whose children had previously participated in early intervention or preschool special education programs and who were 5 to 9 years of age at the time the study was completed. The correspondence included a stamped postcard that interested parents returned to the investigators. A letter further explaining the study together with the survey described below was sent to each parent returning a postcard.

Table 1 shows the background characteristics of the survey participants in the study, and Table 2 shows the preschool and school-age status of the children who participated in an early intervention or preschool program, or both. All but one respondent was a child's mother. More of the PA parents were 
Table 1. Background characteristics of the parents completing the family surveys

\begin{tabular}{|c|c|c|c|c|}
\hline \multirow{2}{*}{ Characteristics } & \multicolumn{2}{|c|}{ North Carolina } & \multicolumn{2}{|c|}{ Pennsylvania } \\
\hline & Number & Percentage & Number & Percentage \\
\hline \multicolumn{5}{|l|}{ Parent age (Years) } \\
\hline $20-29$ & 4 & 14 & 1 & 4 \\
\hline $30-39$ & 16 & 55 & 12 & 52 \\
\hline $40-47$ & 9 & 31 & 10 & 44 \\
\hline \multicolumn{5}{|l|}{ Parent education } \\
\hline Less than high school & 3 & 10 & 0 & 0 \\
\hline High school graduate & 12 & 42 & 7 & 30 \\
\hline Some college & 7 & 24 & 5 & 22 \\
\hline College graduate & 7 & 24 & 11 & 48 \\
\hline \multicolumn{5}{|l|}{ Marital status } \\
\hline Married/living with a partner & 19 & 65 & 19 & 82 \\
\hline Divorced or separated & 8 & 28 & 2 & 9 \\
\hline Single or never married & 2 & 7 & 2 & 9 \\
\hline \multicolumn{5}{|l|}{ Race } \\
\hline White & 26 & 90 & 21 & 91 \\
\hline African American & 2 & 7 & 2 & 9 \\
\hline Native American & 1 & 3 & 0 & 0 \\
\hline \multicolumn{5}{|l|}{ Family socioeconomic status ${ }^{a}$} \\
\hline Low & 0 & 0 & 2 & 9 \\
\hline Low-middle & 10 & 34 & 0 & 0 \\
\hline Middle & 6 & 21 & 5 & 22 \\
\hline Middle-high & 8 & 28 & 7 & 30 \\
\hline High & 5 & 17 & 9 & 39 \\
\hline
\end{tabular}

${ }^{a}$ Hollingshead (1975) four-factor measure of socioeconomic status.

Table 2. Selected characteristics of the child participants

\begin{tabular}{|c|c|c|c|c|}
\hline \multirow[b]{2}{*}{ Characteristics } & \multicolumn{2}{|c|}{ North Carolina } & \multicolumn{2}{|c|}{ Pennsylvania } \\
\hline & Number & Percentage & Number & Percentage \\
\hline \multicolumn{5}{|l|}{ Child diagnosis } \\
\hline Physical disability & 4 & 15 & 6 & 26 \\
\hline Intellectual disability & 3 & 11 & 10 & 44 \\
\hline Sensory disability & 2 & 7 & 0 & 0 \\
\hline Speech disability & 4 & 15 & 4 & 17 \\
\hline \multicolumn{5}{|l|}{ Preschool experiences } \\
\hline Early intervention and preschool & 14 & 48 & 18 & 78 \\
\hline Preschool only & 15 & 52 & 5 & 22 \\
\hline \multicolumn{5}{|l|}{ Child's grade level } \\
\hline Kindergarten & 9 & 31 & 9 & 39 \\
\hline First & 3 & 10 & 5 & 22 \\
\hline Second & 5 & 17 & 6 & 26 \\
\hline Third & 12 & 41 & 3 & 13 \\
\hline \multicolumn{5}{|l|}{ Child's school placement } \\
\hline Primarily regular class & 2 & 7 & 4 & 17 \\
\hline Regular class/some pull-out & 14 & 48 & 4 & 17 \\
\hline Regular class/special education class & 8 & 28 & 9 & 39 \\
\hline Special education class only & 5 & 17 & 6 & 26 \\
\hline
\end{tabular}

from higher socio-economic backgrounds compared to the NC parents, $\chi^{2}=12.78, d f=4, p=.0124$. Additionally, a larger percentage of PA children participated in both birth to age three and age three to five early intervention and preschool programs, $\chi^{2}=4.87, d f=1, p=.0273$, compared to the NC child participants. The children in PA had more physical and intellectual disabilities and fewer learning disabilities, $\chi^{2}=13.94, d f=5, p=.0160$, compared to the children in NC.

\subsection{Survey}

The parent survey included three sections. Section one included 24 items, divided into three sets of eight family- 
centered, eight individualized and developmentally appropriate, and eight integrated and coordinated practices. Each item had two parts. The first part asked the respondents to indicate the extent to which they desired each of the practices for themselves or their children (desired practices) and the second part asked the respondents to indicate the extent to which each of the practices occurred or happened for their child and family (experienced practices). Each of the items was rated on a 3-point scale ranging from Not-At-All (desired or experienced), (desired or experienced) A Little, or (desired or experienced) A Lot with their child or family. Section two elicited parent descriptions of problems or concerns they encountered with school personnel and the kinds of practices school personnel used to create positive family-school relationships and family participation and involvement in their children's education. Section three asked for background information about the respondent, his/her child who received either early intervention or preschool education, or both, and family.

\subsection{Methods of Analysis}

An iterative data analysis process was used to evaluate the match or mismatch between desired and experienced practices. First, we computed the percentage of participants who strongly desired each of the 24 practices constituting the focus of investigation were strongly desired was operationally defined as responses rated Desired A Lot. Second, we computed the percentage of respondents who both desired and experienced each of the practices where experienced was operationally defined as Experienced a Lot. The McNemar test for matched-pairs data (Siegel \& Castellan, 1988) was used to determine if the proportions of desired and experienced practices were the same or different. Third, we computed matched-pairs $t$-tests using the 1 to 3 item ratings in order to be able to compute the mean difference effect sizes for each of the 24 sets of practices to determine the magnitude of the differences between desired and experienced practices (Dunst \& Hamby, 2012). Fourth, we calculated summed scores for each set of practices (family-centered, developmentally appropriate, and integrated and coordinated) and computed between types of practices $F$-tests for both the desired and experienced practices. This permitted us to determine if any of the three kinds of practices differed in terms of desired and experienced practices.

Barriers and solutions to desired practices were identified by asking participants to describe, following their ratings of each set of desired and experienced practices, the (a) problems or concerns they encountered in interactions with school personnel and (b) kinds of practices school personnel used that proved effective in work with their children and families. Responses were sorted into categories by the principal investigator where two research assistants independently determined agreement or disagreement with the responses assigned to each category. Disagreements were resolved by discussions among all three researchers.

\section{Result}

Preliminary analyses were conducted to determine if the parents' response patterns differed as a function of the following background variables: Setting (PA vs. NC), early childhood experience (early intervention and preschool vs. preschool only), parent age and education, respondent marital status (married vs. not married), race (white vs. nonwhite), and family socioeconomic status. Separate one-way ANOVAs were conducted with each of the background measures as blocking variables and each of the 24 desired and 24 experienced practice responses as the dependent measures. The number of significant differences did not exceed what would have been expected by chance and therefore the results are presented for both samples of participants combined.

\subsection{Family-centered practices}

\subsubsection{Desired vs. experienced practices}

Table 3 shows the percentage of parents who indicated they strongly desired the eight different family-centered practices and the percentage of these same parents who indicated they or their children experienced the practices a lot. In all eight analyses, a smaller percentage of parents reported experiencing the practices compared to desired practices as evidenced by the matched-pairs chi-square results. On average, $76 \%(\mathrm{SD}=9)$ of the parents strongly desired the eight family-centered practices, but only $25 \%(\mathrm{SD}=6)$ of the parents, on average, reported experiencing the practices. These differences were confirmed by the matched-pairs $t$-tests and the magnitude of the mean difference effect sizes for these comparisons. The $t$-tests for the between condition comparisons (desired vs. experienced) ranged between $t \mathrm{~s}=4.99$ and $5.86, d f \mathrm{~s}=51, p \mathrm{~s}=.0000$, where the average mean difference effect sizes for these comparisons was $1.02(\mathrm{SD}=11$, Range $=.88$ to 1.17). 
Table 3. Percentage of respondents indicating that they desired and experienced family-centered practices

\begin{tabular}{|c|c|c|c|c|}
\hline Family-centered practices & $\begin{array}{l}\text { Desired the } \\
\text { practice }\end{array}$ & $\begin{array}{l}\text { Experienced } \\
\text { the practice }\end{array}$ & $\chi^{2}$ & $\begin{array}{l}p- \\
\text { value }\end{array}$ \\
\hline $\begin{array}{l}\text { School staff work in a collaborative manner with families to } \\
\text { achieve outcomes for students and families }\end{array}$ & 88.7 & 34.0 & 23.52 & .0000 \\
\hline $\begin{array}{l}\text { School staff seek information from parents about family } \\
\text { desires, concerns, and priorities for their children }\end{array}$ & 81.5 & 25.9 & 22.09 & .0000 \\
\hline $\begin{array}{l}\text { School philosophy addresses the needs, priorities, and well- } \\
\text { being of families }\end{array}$ & 80.8 & 32.7 & 19.50 & .0000 \\
\hline Parents play a leadership role in deciding IEP $^{\mathrm{b}}$ goals & 77.4 & 28.3 & 20.57 & .0000 \\
\hline Parents take a leadership role in planning IEP assessments & 75.5 & 22.6 & 20.16 & .0000 \\
\hline $\begin{array}{l}\text { Parents make final decisions and choices about whether they } \\
\text { want schools to address family issues }\end{array}$ & 75.5 & 20.8 & 23.52 & .0000 \\
\hline $\begin{array}{l}\text { School staff are responsive to the concerns of all family } \\
\text { members }\end{array}$ & 69.2 & 23.1 & 18.62 & .0000 \\
\hline $\begin{array}{l}\text { Parents coordinate school and nonschool services for their } \\
\text { children }\end{array}$ & 57.4 & 16.7 & 10.70 & .0011 \\
\hline
\end{tabular}

aPercentage of respondents who both desired and experienced the practices.

${ }^{\mathrm{b}} \mathrm{IEP}=$ Individualized education plan.

3.1.2 Between types of family-centered practices comparisons

The between type of practices comparisons indicated that the parents' differentially desired the eight familycentered practices, $F(7,357)=4.14, p=.0002$, and also differentially experienced the practices, $F(7,357)=3.61$, $p=.0009$. Six of the eight practices were desired by $75 \%$ or more of the parents (Table 3 ). One of the familycentered practices ("parents coordinate services for their children") was desired by only about half of the parents and only $17 \%$ of these same parents reported experiencing this practice.

Post hoc follow-up analyses found that fewer parents desired the "parents coordinate services for their children" practice compared to three other family-centered practices (school philosophy, school-family collaboration, and school staff seek family input). There were no other statistically significant differences between any of the other desired practices. The post hoc follow-up analyses of the experienced practices found statistically significant differences between "parents coordinate services for their children" and both "school staff work in a collaborative manner with parents" and "school philosophy addressed family needs and concerns." Fewer parents experienced the former practice compared to the latter practice.

\subsection{Individualized and developmentally appropriate practices}

3.2.1 Desired vs. experienced practices

The parents' responses to the individualized and developmentally appropriate practices are shown in Table 4 . Fewer percentages of parents reported their children experiencing all eight practices compared to the practices desired by the parents as evidenced by the statistically significant matched-pairs chi-square results. 
Table 4. Percentage of respondents indicating that they desired and their children experienced individualized and developmentally appropriate practices

\begin{tabular}{|c|c|c|c|c|}
\hline Developmentally appropriate practices & $\begin{array}{l}\text { Desired } \\
\text { the } \\
\text { practice }\end{array}$ & $\begin{array}{l}\text { Experienced } \\
\text { the practice }\end{array}$ & $\chi^{2}$ & $\begin{array}{l}p \text { - } \\
\text { value }\end{array}$ \\
\hline $\begin{array}{l}\text { School staff help students participate in regular classroom } \\
\text { activities }\end{array}$ & 84.3 & 23.5 & 25.49 & .0000 \\
\hline $\begin{array}{l}\text { School practices place equal emphasis on academic skills, social } \\
\text { and physical development, and art education }\end{array}$ & 78.4 & 39.2 & 9.00 & .0027 \\
\hline $\begin{array}{l}\text { Students with disabilities work on the same subject areas as } \\
\text { students without disabilities }\end{array}$ & 75.5 & 32.1 & 20.17 & .0000 \\
\hline $\begin{array}{l}\text { Classroom practices have all students work together in pairs or } \\
\text { small groups }\end{array}$ & 67.3 & 40.4 & 11.27 & .0008 \\
\hline $\begin{array}{l}\text { Classrooms are set up in activity areas and all students are } \\
\text { allowed to work on the activity of their choice }\end{array}$ & 61.5 & 30.8 & 10.89 & .0010 \\
\hline $\begin{array}{l}\text { Children with and without disabilities work together in small } \\
\text { groups }\end{array}$ & 56.6 & 22.6 & 12.80 & .0003 \\
\hline $\begin{array}{l}\text { Students have the opportunity to choose and decide what they } \\
\text { want to learn }\end{array}$ & 45.1 & 17.6 & 9.00 & .0027 \\
\hline $\begin{array}{l}\text { Children with and without disabilities choose how they spend } \\
\text { their time in the classroom }\end{array}$ & 37.3 & 9.8 & 9.00 & .0027 \\
\hline
\end{tabular}

aPercentage of respondents who both desired and experienced the practices.

An average of $63 \%(\mathrm{SD}=16)$ of the parents desired the eight practices, but an average of only $23 \%(\mathrm{SD}=$ 11) of the parents reported their children experienced the practices. These differences were confirmed by the matched-pairs $t$-tests results and mean difference sizes of effects for the desired vs. experienced comparisons. The eight between condition comparisons were all statistically significant, $t \mathrm{~s}=3.27$ to $6.62, d f s=51, p \mathrm{~s}=.0020$ to .0000 , where the average mean difference effect sizes for these comparisons was $.85(\mathrm{SD}=.20$, Range $=.63$ to 1.22$)$.

3.2.2 Between types of developmentally appropriate practices comparisons

The between type of practices comparisons indicated that the parents' differentially desired the eight individualized and developmentally appropriate practices, $F(7,357)=9.04, p=.0000$, and also reported that their children differentially experienced the practices, $F(7,357)=5.36, p=.0000$. Only four of the individualized and developmentally appropriate practices were desired by two-thirds or more of the parents, whereas two practices were desired by fewer than half of the parents (Table 4). Both of the latter practices were ones that involved student self-directed learning.

The post hoc follow-up analyses of the desired practices found that two of the inclusion-related practices ("school practices place equal emphasis on academic and nonacademic education" and "all students work together in groups") differed statistically from the two student self-directed learning practices ("children decide how to spend time in the classroom" and "students decide what they want to learn"). Fewer parents desired the former two practices compared to the latter to practices. The post hoc analyses of the experienced practices found that fewer parents reported the use of the "students decide what they want to learn" practice compared to both "school practices place equal emphasis on academic and nonacademic learning" and "all students work together in groups" practices. There were no statistically significant differences between any of the other desired or experienced individualized and developmentally appropriate practices.

\subsection{Integrated and coordinated practices}

3.3.1 Desired vs. experienced practices

Table 5 shows the parents' responses to the integrated and coordinated practices. There were statistically significant differences in the percentages of parents who desired the practices compared the percentages of parents who reported themselves and their children experiencing all eight of the practices as evidenced by the chi-square results. An average of $78 \%(\mathrm{SD}=13)$ of the parents desired the eight integrated and coordinated practices, but an average of only $28 \%(\mathrm{SD}=13)$ of the parents reported experiencing the practices. All eight matched-pairs $t$-tests 
were also statistically significant for the desired vs. experienced comparisons, $t \mathrm{~s}=3.12$ to $10.06, d f_{s}=51, p \mathrm{~s}$ $=.0030$ to .0000 , where the average mean difference effect size was $1.09(\mathrm{SD}=.49$, Range $=.50$ to 2.07).

Table 5. Percentage of respondents indicating that they desired and experienced integrated and coordinated practices

\begin{tabular}{|c|c|c|c|c|}
\hline Integrated and coordinated practices & $\begin{array}{l}\text { Desired the } \\
\text { practice }\end{array}$ & $\begin{array}{l}\text { Experienced } \\
\text { the practice }\end{array}$ & $\chi^{2}$ & $\begin{array}{c}p- \\
\text { value }\end{array}$ \\
\hline $\begin{array}{l}\text { Therapy and special services staff work closely with regular } \\
\text { and special education teachers to meet } \text { IEP }^{\mathrm{b}} \text { goals }\end{array}$ & 92.0 & 34.0 & 23.52 & .0000 \\
\hline $\begin{array}{l}\text { School personnel and parents work together to develop a } \\
\text { child's IEP }\end{array}$ & 90.4 & 40.4 & 20.57 & .0000 \\
\hline $\begin{array}{l}\text { IEP includes child goals and objectives in both school and } \\
\text { nonschool activities }\end{array}$ & 90.2 & 33.3 & 29.00 & .0000 \\
\hline $\begin{array}{l}\text { A school staff member is designated to coordinate services } \\
\text { for students with disabilities }\end{array}$ & 83.3 & 33.3 & 16.33 & .0001 \\
\hline $\begin{array}{l}\text { IEP activities are implemented primarily in the student's } \\
\text { regular classroom }\end{array}$ & 72.0 & 30.0 & 15.70 & .0001 \\
\hline $\begin{array}{l}\text { School personnel work with community-based programs } \\
\text { outside the school to increase learning opportunities }\end{array}$ & 70.6 & 3.9 & 31.11 & .0000 \\
\hline $\begin{array}{l}\text { Students with disabilities are educated primarily in regular } \\
\text { education classrooms }\end{array}$ & 65.4 & 32.7 & 9.80 & .0017 \\
\hline $\begin{array}{l}\text { Therapy and other specialized services are implemented } \\
\text { primarily in the student's regular classroom }\end{array}$ & 58.0 & 18.0 & 10.67 & .0011 \\
\hline
\end{tabular}

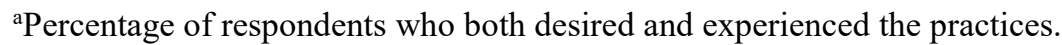

${ }^{\mathrm{b}} \mathrm{IEP}=$ Individualized education plan.

3.3.2 Between types of integrated and coordinated practices comparisons

The between type of practices comparisons indicated that the parents' differentially desired the eight integrated and coordinated practices, $F(7,357)=7.09, p=.0000$, and also reported that their children and families differentially experienced the practices, $F(7,357)=7.83, p=.0000$. All of the practices except one were desired by two-thirds or more of the parents, whereas integrated therapy services were desired by only $58 \%$ of the parents (Table 5).

The post hoc follow-up analyses of the desired practices found fewer parents desired "students with disabilities are educated in regular classrooms" compared to three other desired practices (working together to develop a child's IEP, IEP goals and objectives, and therapy staff and teachers work together). Fewer parents also desired "therapy staff and teachers work together" less compared to two other practices (working together to develop a child's IEP and IEP goals and objectives). The post hoc follow-up analyses of the experienced practices found fewer parents reporting "school personnel works with community-based programs outside of school" compared to all of the other integrated and coordinated practices. Fewer parents also reported their children experiencing less "therapy and other specialized services implemented in regular classrooms" compared to "school personnel and parents work together to develop a child's IEP."

\subsection{Between types of ECI practices comparisons}

Whether the three different types of practices (family-centered, developmentally appropriate, and integrated and coordinated) that were the focus of investigation were differentially desired and experienced by the children and parents was determined by three between types of practices ANOVAs, one for desired practices and one for experienced practices. The results showed that the three types of practices were differentially desired by the parents, $F(2,102)=6.77, p=.0017$, but not differentially experienced by the children and parents, $F(2,102)=1.74, p$ $=.1800$. The results are shown in Figure 1 in terms of the average percentage of desired and experienced practices. Post hoc follow-up analyses of the desired practices showed that the individualized and developmentally appropriate practices were desired less than both of the other two types of practices, and that family-centered practices and integrated and coordinated did not differ significantly in terms of the desire for the practices. As can be seen in Figure 1, the average percentage of practices experienced by the children and parents were nearly 
identical.

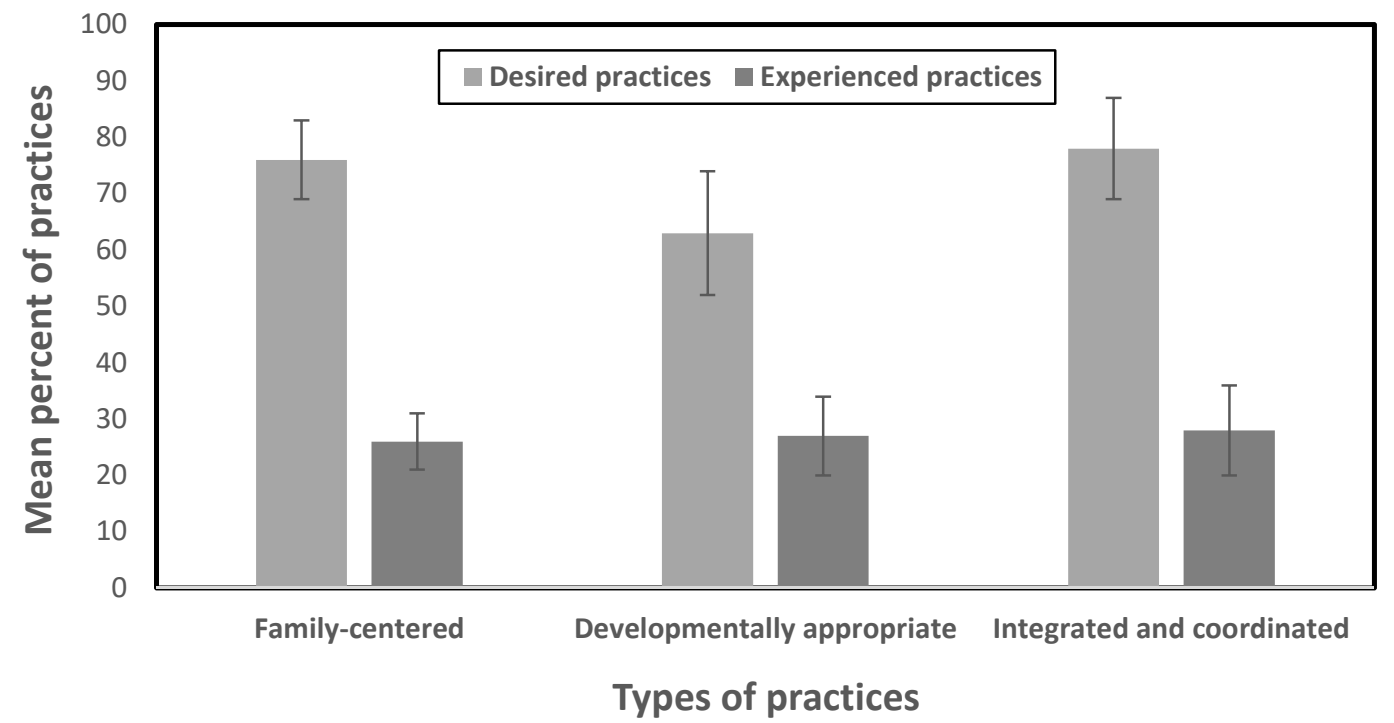

Figure 1. Mean percent of practices desired by the parents and experienced by the Parents and their children. (Note. Error bars $=95 \%$ confidence intervals.)

\subsection{Barriers and solutions}

Thirty of the 52 survey participants (58\%) listed one or more problems and concerns, 16 respondents $(31 \%)$ indicated no problems, and 6 respondents (11\%) gave no responses. Forty-three respondents (82\%) listed one or more aspects of positive family-school transactions, 3 respondents $(6 \%)$ provided no examples of effective practices, and 6 respondents $(11 \%)$ gave no responses. Table 6 shows the number and percentage of parents who recorded barriers and solutions to increasing school staff use of these three sets of practices. Fifty-two (52) different problems and concerns were listed as barriers, and 73 school practices were listed as solutions.

Practices that were nonresponsive to family requests and the lack of family-school communication and collaboration were the most frequently mentioned problems. The lack of school personnel use of appropriate instructional practices (particularly those involving the respondent's children's participation in typical school programs and activities) and the lack of a positive attitude toward parents or children, or both, were the second most frequently mentioned problems. Three of the four most frequently mentioned barriers involved poor familyschool relationships. 
Table 6. Number and percentage of barriers and solutions identified by the survey participants

\begin{tabular}{lcc}
\hline Barriers and solutions & Number & Percentage \\
\hline Barriers & & \\
Unresponsive and inflexible school practices & 13 & 25 \\
Poor school personnel communication/collaboration & 13 & 25 \\
Inappropriate child instructional practices & 10 & 19 \\
Poor school personnel attitudes & 8 & 15 \\
Staff and material shortages & 5 & 10 \\
Other (e.g., lack of staff commitment, staff time constraints) & 3 & 6 \\
Solutions & & \\
Positive family-school collaboration and communication & 35 & 48 \\
Responsive and flexible school practices & 19 & 26 \\
Information regarding parent rights & 5 & 7 \\
Developmentally appropriate child instructional practices & 4 & 5 \\
Team planning processes and procedures & 3 & 4 \\
Child acceptance and inclusion & 2 & 3 \\
Appropriate resources and materials & 1 & 1 \\
Other (nonspecific) & 4 & 5
\end{tabular}

The practices mentioned most frequently as contributing to the children and families experiencing desired practices were (1) positive family-school communication and collaboration and (2) school personnel's use of responsive, individualized, and flexible practices with the parents or children, or both. The other types of practices were infrequently mentioned by the parents.

A comparison between the practices considered barriers and solutions find the same practices are mentioned as concerns and problems and practices contributing to positive factors family-school experiences. The findings suggest that a focus on improving family-school relationships, and finding ways for school personnel to become more responsive and flexible to family requests, could contribute to increased school personnel use of the practices constituting the focus of investigation.

\section{Discussion}

The findings from the different sets of analyses indicated that parents differentially desired different types of family-centered practices, individualized and developmentally appropriate child practices, and integrated and coordinated practices and that for all 24 ECI practices constituting the focus of investigation, the majority of the children and parents did not experience desired practices. Results also indicated that individualized and developmentally appropriate child practices were desired less than family-centered practices and integrated and coordinated practices. Analyses of the barriers and solutions to desired practices showed that poor family-school relationships impeded the provision of desired practices and positive family-school relationships contributed to the provision of desired practices.

Comparisons of the desired vs. experienced practices find fewer differences in the percentage of parents reporting the use of desired developmentally appropriate practices compared to family-centered practices and integrated and coordinated practices. About $30 \%$ of the parents who desired developmentally appropriate practices for their children indicated that these practices were not used with their children. In contrast, about $50 \%$ of the parents who desired family-centered practices and integrated and coordinated practices did not experience these practices. These differences are most likely due to the fact that developmentally appropriate practices are generally seen as within the purview of "what schools do" (Copple, Bredekamp, Koralek, \& Charner, 2014), whereas neither family-centered practices nor integrated and coordinated practices are generally not seen as a major focus of school practices (Dunst \& Trivette, 2009; Institute of Medicine, 1997).

It is instructive to compare the most and least desired practices to identify the response patterns of the parents participating in the study. These two sets of practices are shown in Table 7. The most desired practices are all student-focused and entail what school personnel do either independently or in collaboration with students' parents to achieve individualized student goals and objectives using student-specific practices. All but one of the least desired practices are also student-specific but emphasize student self-directed learning as part of the inclusion of children with disabilities in regular classroom activities. The results "paint a clear picture" of what are considered important school practices to parents of children with disabilities in the early elementary grades. 
Table 7. Most and least desired early childhood intervention practices for use in the early elementary grades

\begin{tabular}{lc}
\hline Early childhood intervention practices & $\begin{array}{c}\text { Percent of } \\
\text { parents }\end{array}$ \\
\hline Most desired practices & 92.0 \\
Therapy and special services staff work closely with regular and special education teachers & 90.4 \\
to meet a child IEP goals & 90.2 \\
School personnel and parents work together to develop a child's IEP & 88.7 \\
IEP includes child goals and objectives in both school and nonschool activities & 84.3 \\
School staff works in a collaborative manner with families to achieve outcomes for students & 83.3 \\
and families & 58.0 \\
School staff help students (with disabilities) participate in regular classroom activities & 57.4 \\
A school staff member is designated to coordinate services for students with disabilities & 56.6 \\
Least desired practice & 45.1 \\
Therapy and other specialized services are implemented primarily in students' & \\
regular classroom activities & 37.3 \\
Parents coordinate school and nonschool services for their children & \\
Children with and without disabilities work together in small groups & \\
Students (with disabilities) have the opportunity to choose and decide what they & \\
want to learn & \\
Children with and without disabilities choose how they spend their time in \\
regular classroom activities
\end{tabular}

\subsection{Implications for practice}

There are a number of implications from the findings described in this paper for increasing school personnel use of parent desired practices for their children and families. The first implication for practice is based on the fact that not a single practice was strongly desired by all of the parents. This indicates a need for a highly individualized approach to identifying parent-desired practices so the school personnel can be responsive to specific parent requests. The practices listed in Tables 3,4 , and 5 can be used as checklists for identifying desired practices and tailoring school-family interactions to specific parent desires and priorities (see especially Gawande, 2009). The second implication for practice is based on the fact that the same school personnel practices were identified as both barriers and solutions to adoption and use of desired practices where poor family-school relationships impeded the use of the practices and positive family-school relationships promoted the use of the practices. Results indicated that school personnel sensitivity and responsiveness to parent requests and positive attitudes toward and interactions with parents and other family members were practices that were found to increase the use of parent desired practices (see especially Christenson \& Reschly, 2010; Epstein et al., 2018). Strengthening school personnel family-school relationships in ways that are responsive to family-desired practices including, but not limited to the practices described in this paper, will require professional development and school leadership to promote school personnel acquisition of the knowledge and skills to effectively work with parents and other family members (Auerbach, 2010; J. L. Epstein \& Sanders, 2006). Leadership and professional development, to have meaningful benefits in terms of affecting changes in school personnel practices, needs to be evidence-based and found to be related to outcomes of interest including the practices constituting the focus of investigation described in this paper (Dunst, Bruder, \& Hamby, 2015; Dunst, Bruder, Hamby, Howse, \& Wilkie, 2018; Dunst, Trivette, \& Hamby, 2010).

\subsection{Implications for Research}

The results of the study have a number of implications for research. More in-depth analyses of why parents consider certain practices more important than others would help teachers and other school personnel better understand parents' perspectives of desired school practices. More in-depth investigation of barriers and solutions to improving school-family relationships would inform changes that need to be made to be more responsive to parent desired practices for their children and themselves.

\section{Acknowledgments}

This study described in this paper was supported, in part, with funding from the U.S. Department of Education, Office of Special Education Programs (H024Q50001). The opinions expressed, however, are those of the authors and do not necessarily represent those of the Department or Office.

\section{Conflicts of interests}

The authors declare no conflicts of interests. 


\section{Authors' contributions}

CJD designed the study, determined the appropriate methods of analysis, and wrote the manuscript. DWH conducted the data analysis.

\section{References}

Aaron, C., Chiarello, L. A., Palisano, R. J., Gracely, E. J., O'Neil, M., \& Kolobe, T. (2014). Relationships among family participation, team support, and intensity of early intervention services. Physical \& Occupational Therapy In Pediatrics, 34(4), 343-355. doi:10.3109/01942638.2014.899286

Auerbach, S. (2010). Beyond coffee with the principal: Toward leadership for authentic school-family partnerships. Journal of School Leadership, 20(6), 728-757. Retrieved from https://doi.org/10.1177/105268461002000603 doi:10.1177/105268461002000603

Bailey, D. B., Jr. (1994). Working with families of children with special needs. In M. Wolery \& J. S. Wilbers (Eds.), Including children with special needs in early childhood programs (pp. 23-44). Washington, DC: National Association for the Education of Young Children.

Bailey, D. B., Jr., \& McWilliam, P. J. (1993). The search for quality indicators. In P. J. McWilliam \& D. B. Bailey, Jr. (Eds.), Working together with children and families: Case studies in early intervention (pp. 3-20). Baltimore, MD: Brookes.

Bruder, M. B. (1994). Working with members of other disciplines: Collaboration for success. In M. Wolery \& J. S. Wilbers (Eds.), Including children with special needs in early childhood programs (pp. 45-70). Washington, DC: National Association for the Education of Young Children.

Bruder, M. B. (2005). Service coordination and integration in a developmental systems approach to early intervention. In M. J. Guralnick (Ed.), The developmental systems approach to early intervention (pp. 29-58). Baltimore, MD: Brookes.

Christenson, S. L., \& Reschly, A. L. (Eds.). (2010). Handbook of school-family partnerships. New York, NY: Routledge.

Copple, C., Bredekamp, S., Koralek, D. G., \& Charner, K. (Eds.). (2014). Developmentally appropriate practice: Focus on children in first, second, and third grades. Washington, DC: National Association for the Education of Young Children.

Dunst, C. J. (2002). Family-centered practices: Birth through high school. Journal of Special Education, 36, 139147. doi:10.1177/00224669020360030401

Dunst, C. J. (2017). Research foundations for evidence-informed early childhood intervention performance checklists. Education Sciences, 7(4), Number 78. Retrieved from http://www.mdpi.com/2227-7102/7/4/78 doi:10.3390/educsci7040078

Dunst, C. J., Bruder, M. B., \& Hamby, D. W. (2015). Metasynthesis of in-service professional development research: Features associated with positive educator and student outcomes Educational Research and Reviews, 10(12), 1731-1744. doi:10.5897/ERR2015.2306

Dunst, C. J., Bruder, M. B., Hamby, D. W., Howse, R., \& Wilkie, H. (2018). Meta-analysis of the relationships between different leadership practices and organizational, teaming, leader and employee outcomes. Journal of International Education and Leadership, 8(2), 1-45. Retrieved from https://files.eric.ed.gov/fulltext/EJ1192239.pdf

Dunst, C. J., \& Espe-Sherwindt, M. (2016). Family-centered practices in early childhood intervention. In B. Reichow, B. A. Boyd, E. E. Barton, \& S. L. Odom (Eds.), Handbook of early childhood special education (pp. 37-55). Switzerland: Springer International.

Dunst, C. J., \& Hamby, D. W. (2012). Guide for calculating and interpreting effect sizes and confidence intervals in intellectual and developmental disabilities research studies. Journal of Intellectual and Developmental Disability, 37, 89-99. doi:10.3109/13668250.2012.673575

Dunst, C. J., \& Trivette, C. M. (2009). Importance, adoption and use of family-centered principles and practices in the early elementary grades. Asheville, NC: Winterberry Press.

Dunst, C. J., Trivette, C. M., \& Hamby, D. W. (2008). Research synthesis and meta-analysis of studies of familycentered practices. Asheville, NC: Winterberry Press.

Dunst, C. J., Trivette, C. M., \& Hamby, D. W. (2010). Meta-analysis of the effectiveness of four adult learning methods and strategies. International Journal of Continuing Education and Lifelong Learning, 3(1), 91-112. Retrieved from http://hdl.voced.edu.au/10707/41

Epstein, J. L., \& Sanders, M. G. (2006). Prospects for change: Preparing educators for school, family, and community partnerships. Peabody Journal of Education, 81(2), 81-120. doi:10.1207/S15327930pje8102_5

Epstein, J. L., Sanders, M. G., Sheldon, S. B., Simon, B. S., Salinas, K. C., Jansorn, N. R., . . Williams, K. J. (2018). School, family, and community partnerships: Your handbook for action (4th ed.). Thousand Oaks, CA: Corwin.

Farley, K. S., Brock, M. E., \& Winterbottom, C. (2017). Evidence-based practices: Providing guidance for early 
childhood practitioners. Journal of Research in Childhood Education, 32(1), 1-13. Retrieved from https://doi.org/10.1080/02568543.2017.1387205 doi:10.1080/02568543.2017.1387205

Gawande, A. (2009). The checklist manifesto: How to get things right. New York: Metropolitan Books.

Hollingshead, A. B. (1975). Four factor index of social status. Unpublished manuscript, Yale University, Department of Sociology, New Haven, CT.

Institute of Medicine. (1997). Schools and health: Our nation's investment. Washington, DC: The National Academies Press. Retrieved from https://doi.org/10.17226/5153.

Kavale, K. A., \& Forness, S. R. (2000). History, rhetoric, and reality: Analysis of the inclusion debate. Remedial and Special Education, 21(5), 279-296. doi:10.1177/074193250002100505

Le Tendre, M. J. (2000). Bridging the gap between early childhood education and primary education. Journal of Education for Students Placed at Risk, 4, 219-225.

McKenzie, E. N. (2013). National Board Certification and Developmentally Appropriate Practices: Perceptions of impact. Journal of Research in Childhood Education, 27(2), 153-165. doi:10.1080/02568543.2013.766661

McWilliam, R. A., Maxwell, K. L., \& Sloper, K. M. (1999). Beyond "involvement": Are elementary schools ready to be family-centered? School Psychology Review, 28, 378-394.

Niemeyer, J. A., Cassidy, D. J., Collins, E., \& Taylor, B. (1999). Facilitating individual planning for young children with disabilities in developmentally appropriate classrooms. Early Childhood Education Journal, 26, 255262. doi:10.1023/A:1022967723742

Odom, S. L., Buysse, V., \& Soukakou, E. (2011). Inclusion for young children with disabilities: A quarter century of research perspectives. Journal of Early Intervention, 33(4), 344-356. doi:10.1177/1053815111430094

Odom, S. L., \& McLean, M. E. (Eds.). (1996). Early intervention/early childhood special education: Recommended practices. Austin, TX: PRO-ED.

Peck, C. A., Odom, S. L., \& Bricker, D. D. (Eds.). (1993). Integrating young children with disabilities into community programs: Ecological perspectives on research and implementation. Baltimore, MD: Brookes.

Rainforth, B., \& York-Barr, J. (1997). Collaborative teams for students with severe disabilities: Integrating therapy and educational services (2nd ed.). Baltimore, MD: Brookes.

Ruble, L., \& McGrew, J. H. (2013). Teacher and child predictors of achieving IEP goals of children with autism. Journal of Autism and Developmental Disorders, 43(12). Retrieved from https://www.ncbi.nlm.nih.gov/pmc/articles/PMC3825843/pdf/nihms-516438.pdf doi:10.1007/s10803-0131884-X

Salisbury, C. (1992). Parents as team members: Inclusive teams, collaborative outcomes. In B. Rainforth, J. YorkBarr, \& C. MacDonald (Eds.), Collaborative teams for students with severe disabilities (pp. 43-66). Baltimore, MD: Brookes.

Siegel, S., \& Castellan, N. J., Jr. (1988). Nonparametric statistics for the behavioral sciences (2nd ed.). New York, NY: McGraw-Hill.

Trivette, C. M., Dunst, C. J., Hamby, D. W., \& Meter, D. (2012). Research synthesis of studies investigating the relationships between practitioner beliefs and adoption of early childhood intervention practices. Practical Evaluation Reports, $4(1), \quad 1-19 . \quad$ Retrieved from http://www.puckett.org/Practical\%20Evaluation\%20reports/CPE_Report_Vol4No1.pdf

Turbiville, V. P., Turnbull, A. P., Garland, C. W., \& Lee, I. M. (1996). Development and implementation of IFSPs and IEPs: Opportunities for empowerment. In S. L. Odom \& M. E. McLean (Eds.), Early intervention/early childhood special education: Recommended practices (pp. 77-100). Austin, TX: PRO-ED.

Wolery, M., \& Wilbers, J. S. (Eds.). (1994). Including children with special needs in early childhood programs. Washington, DC: National Association for the Education of Young Children.

Yeboah, D. A. (2002). Enhancing transition from early childhood phase to primary education: Evidence from the research literature. Early Years, 22(1), 51-68. doi:10.1080/09575140120111517 